\title{
触 New Disease Reports \\ First report of Tragopogon dubius witches' broom disease associated with a subgroup 16Srl-B phytoplasma in Iran
}

\author{
M. Salehi ${ }^{1 *}$ and E. Salehi ${ }^{2}$ \\ ${ }^{1}$ Plant Protection Research Department, Fars Agricultural and Natural Resources Research and Education Centre, AREEO, \\ Zarghan, P.O. Box 1151-71955, Iran; ${ }^{2}$ Department of Plant Protection, College of Agriculture, Shiraz University, Shiraz, Iran
}

*E-mail: salehi_abarkoohi@yahoo.com

Received: 12 May 2015. Published: 07 Nov 2015. Keywords: virescence, phyllody, PCR

Tragopogon dubius (yellow salsify, Asteraceae) is a perennial herb in Iran. In a survey conducted for phytoplasma diseases in 2014, T. dubius witches' broom disease was observed in vineyards and green areas of Bajgah and Zarghan localities (Fars province, Iran). The characteristic symptoms of $T$. dubius witches' broom were flower virescence and phyllody, crown proliferation and witches' broom (Fig. 1). Since the symptoms were suggestive of phytoplasma infection, plants were assayed for presence of phytoplasma by PCR amplification. Total DNA was extracted from $0.3 \mathrm{~g}$ of midrib tissue of four witches' broom affected and two symptomless $T$. dubius plants (two plants per location), using the procedure of Zhang et al. (1998). Total DNA samples were tested by both direct and nested PCR assays using phytoplasma universal 16S rDNA primer pairs P1/P7 (Deng \& Hiruki, 1991; Schneider et al., 1995) and R16F2n/R16R2 (Gundersen \& Lee, 1996) that amplify fragments of $1800 \mathrm{bp}$ and $1250 \mathrm{bp}$, respectively. Expected fragments were amplified following direct and nested PCR from all symptom-bearing but not from symptomless plants.

P1/P7-primed PCR products amplified from four witches' broom-affected T. dubius plants were separately cloned and sequenced. The full-length $16 \mathrm{~S}$ rDNA sequences displayed $100 \%$ sequence identity with each other. A consensus sequence corresponding to the Bajgah $T$. dubius witches' broom was deposited in GenBank (Accession No. KR262955). A Blast search showed that this sequence had $100 \%$ identity with Oenothera phytoplasma ('Candidatus Phytoplasma asteris') (M30790), representative of subgroup 16SrI-B. Virtual RFLP analysis using $i$ PhyClassifier online tool (http://www.ba.ars. usda.gov/data/mppl/iphyclassifier), carried out with 17 restriction enzymes, indicated the presence of a 16SrI-B phytoplasma in witches' broom-affected T. dubius plants (Fig. 2). Phylogenetic analysis of full length 16S rDNA sequences using MEGA version 5 (Tamura et al., 2011) grouped T. dubius witches' broom phytoplasma with onion yellows phytoplasma (GenBank Accession No. D12569), a member of 16SrI-B subgroup (Fig. 3). To our knowledge this is the first report of natural occurrence and partial molecular characterisation of a phytoplasma associated with $T$. dubius witches' broom disease. A 16SrI-B subgroup phytoplasma has previously been reported as causal agent of rapeseed phyllody disease in Zarghan (Salehi et al., 2011). The significance of diseased T. dubius as natural reservoir of rapeseed phyllody phytoplasma remains to be determined. Aster yellows phytoplasmas were reported in grapevine in several countries. However, possible transmission of $T$. dubius witches' broom phytoplasma to grapevine is yet to be tested.

\section{References}

Deng S, Hiruki C, 1991. Amplification of 16S rRNA genes from culturable and non-culturable mollicutes. Journal of Microbiological Methods 14, 53-61. http://dx.doi.org/10.1016/0167-7012(91)90007-D

Gundersen DE, Lee IM, 1996. Ultrasensitive detection of phytoplasmas by nested-PCR assays using two universal primer pairs. Phytopathologia Mediterranea 35, 144-151.

Salehi M, Izadpanah K, Siampour M, 2011. Occurrence, molecular characterization and vector transmission of a phytoplasma associated with rapeseed phyllody in Iran. Journal of Phytopathology 159, 100-105. http://dx.doi.org/10.1111/j.1439-0434.2010.01731.x

Schneider B, Seemüller E, Smart CD, Kirkpatrick BC, 1995. Phylogenetic classification of plant pathogenic mycoplasma-like organisms or phytoplasmas. In: Razin S, Tully JG, eds. Molecular and Diagnostic Procedures in Mycoplasmology, Vol.1. Academic Press, San Diego, CA, USA, 369-380. http://dx.doi.org/10.1016/B978-012583805-4/50040-6

Tamura K, Peterson D, Peterson N, Stecher G, Nei M, Kumar S, 2011. MEGA5: Molecular evolutionary genetics analysis using maximum likelihood, evolutionary distance, and maximum parsimony methods. Molecular Biology Evolution 28, 2731-2739.

http://dx.doi.org/10.1093/molbev/msr121

Zhang YP, Uyemoto JK, Kirkpatrick BC, 1998. A small-scale procedure for extracting nucleic acids from woody plants infected with various phytoplasmas for PCR assay. Journal of Virological Methods 71, 45-50. http://dx.doi.org/10.1016/S0166-0934(97)00190-0

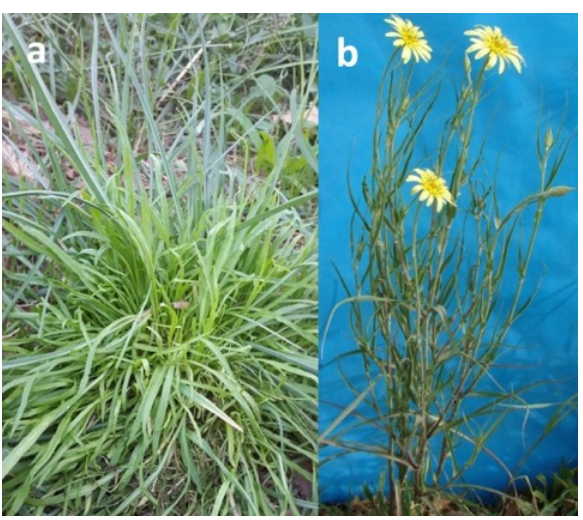

Figure 1

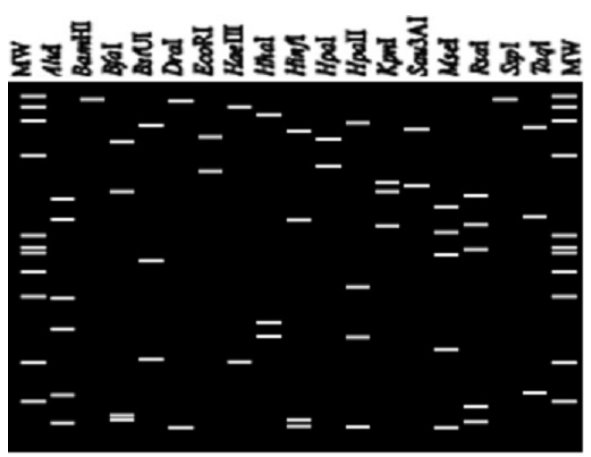

Figure 2

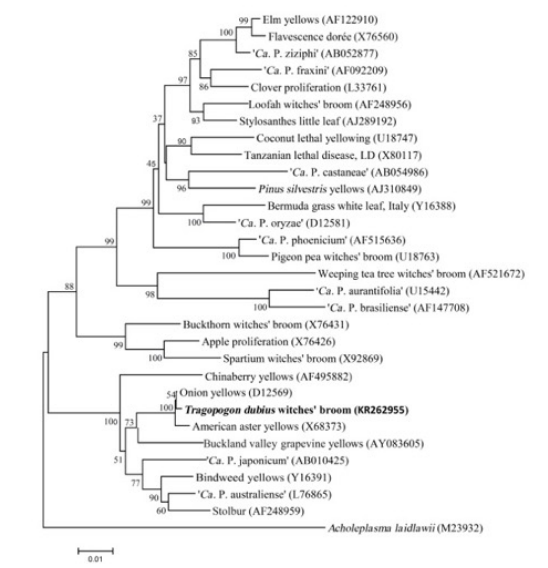

Figure 3

To cite this report: Salehi M, Salehi E, 2015. First report of Tragopogon dubius witches' broom disease associated with a subgroup 16Srl-B phytoplasma in Iran. New Disease Reports 32, 17. http://dx.doi.org/10.5197/j.2044-0588.2015.032.017

(c) 2015 The Authors

This report was published on-line at www.ndrs.org.uk where high quality versions of the figures can be found. 